\title{
THE COMPARISON OF DAIRY PERFORMANCE AND SOME REPRODUCTIVE PARAMETERS OF HOLSTEIN COWS IMPORTED FROM SWEDEN AND THEIR POLISH AGE MATES
}

\author{
E. Czerniawska-Piątkowska, M. Szewczuk, H. Kamieniecki, M. Adamski, A. Bruś, \\ D. Falta
}

Received: November 3, 2006

\begin{abstract}
CZERNIAWSKA-PIĄTKOWSKA, E., SZEWCZUK, M., KAMIENIECKI, H., ADAMSKI, M, BRUŚ, A., FALTA, D.: The comparison of dairy performance and some reproductive parameters of holstein cows imported from Sweden and their Polish age mates. Acta univ. agric. et silvic. Mendel. Brun., 2007, LV, No. 1, pp. 39-44
\end{abstract}

The general aim of the present work was to compare dairy performance and some reproductive parameters of Holstein-Friesian (HF) cows imported from Sweden as an in-calf heifers, and their age mates in Poland. The animals were kept freely on the deep litter on the farm owned by Agro-company "Witkowo" and feeding was based on TMR (total mixed ration) system during whole year. All ration's ingredients (bulky feed, concentrate, miscellaneous additives) were mixed and fed as all-mash. The feed ration depended from the physiological condition of a cow and it was composed of corn and grass ensilage, mash concentrate, crushed corn meal, brewer's grains and beet pulp.

Cows imported from Sweden as in-calf heifers obtained higher milk, fat and protein yield in both lactations comparing to home cows. Significant statistical differences were observed for $\mathrm{kg}$ of milk, $\mathrm{kg}$ of protein, for FCM $(\mathrm{P}<0.01)$ and for $\mathrm{kg}$ of fat $(\mathrm{P}<0.05)$ in $2^{\text {nd }}$ lactation. Fat and protein content in milk was in average higher for home cows $(\mathrm{P}<0.01)$. Big differences $(\mathrm{P}<0.01)$ were observed in SBT (proportion of protein to fat content) and RTB (difference between concentration of fat and protein) at imported cows in $2^{\text {nd }}$ lactation. As far as reproduction parameters (gestation interval, calving interval, insemination index) are concerned was cows from Sweden better too. Heifers from Sweden calved earlier. The usage of high genetic potential of imported cows is possible only with providing them optimum living conditions suitable to their needs.

import, cows, Holstein (HF), milk yield

The artificial insemination of cows and heifers with the semen from Holstein-Friesian bulls has been used in Poland on a large scale since the second half of the 80 's. It has lead to cardinal changes in Polish population of black-white cattle. Nowadays, almost $90 \%$ of tested black-white heifer cows in Poland are hf crossbreeds, and half of them possess over $50 \%$ of $\mathrm{HF}$ genes. The improvement of home cattle has had an influence on animals body conformation and their milk yield, what in consequence is leading to the transformation of this population into unilateral dairy type (LITWIŃCZUK and GULIŃSKI, 2000).

PILARCZYK et al. (2004) suggest that the import of HF heifers with the highest genetic potential is a quicker method to improve dairy yield. In a shorter period of time, providing good management and feeding conditions, we can obtain intended effects.

The new milk quotes system, which was put into 
execution on April 1, 2004, demands from the cattle breeders to take efforts leading to the increase of milk production by the rise in individual milk yield (crossbreeding of home cattle with hf cattle) and by the increase of foundation stock size (import of replacement heifers from EU countries) (KUCZAJ, 2004)

Nowadays, cattle breeders from all countries share the opinion that genetic potential has bigger impact on dairy yield than feeding and management (DYMNICKI et al., 2003; KUČERA et al., 2002).

\section{MATERIALS AND METHODS}

The purpose of the research was to compare the diary performance with some of the reproduction parameters of Holstein-Friesian cows imported from Sweden as in-calf heifers with their age mates in Poland.

The research was conducted on two groups of heifer cows. Group I - Holstein-Friesian cows imported from Sweden in April and May 2002 (100 animals). Group II - home cows with $100 \%$ of HF genes (100 animals).

The animals were kept freely on the deep litter on the farm owned by Agro-company "Witkowo". The removal of manure was performed once in two months with the use of the frontal manure loaders TUR type. The fodder was given three times an day using mash trolley Kverneland KD 714 (capacity 3.5 tons). Cows had a constant access to water using the automatic drinkers.

Heifer's feeding was based on TMR (total mixed ration) system during a whole year. All ration's ingredients (bulky feed, concentrate, miscellaneous additives) were mixed and fed as all-mash. The feed ration depended from the physiological condition of a cow and it was composed of corn and grass ensilage, mash concentrate, crushed corn meal, brewer's grains and beet pulp. The automatic milking was performed in ALPRO system, and cows were milked three times a day.

The comparative analyses of milk yield was based on $\mathrm{A}_{4}$ method of official dairy performance assessment, including the milk, fat and proteins yield (in $\mathrm{kg}$ ) and their percentage content in milk. The differences between those components were also determined (RTB - difference between concentration of fat and proteins, SBT - proportion of protein to fat content). To compare the results of the research from two consecutive 305-days lactations, the standard yield of milk with $4 \%$ of fat content was counted (FCM - fat corrected milk).

Some reproduction parameters like calving interval (CI), gestation interval (GI), artificial insemination index (AII) and age at first calving were also analyzed.

The data were subject to statistical analysis and the mean values $(\bar{x})$, standard deviation $\left(s_{x}\right)$ and coefficient of variation ( $\mathrm{V} \%$ ) were calculated. The significance of differences between means of the groups was defined by Duncan's test with the use of Statistica PL software.

\section{RESULTS AND DISCUSSION}

Table I presents the comparison of milk, fat and protein yield of animals imported from Sweden and home cows in the first and the second lactation. Imported cows in the first lactation obtained $5926 \mathrm{~kg}$ of milk, $238 \mathrm{~kg}$ of fat and $186 \mathrm{~kg}$ of protein, and in the second lactation $7917 \mathrm{~kg}, 301 \mathrm{~kg}$ and $252 \mathrm{~kg}$, respectively. That means that in the first, as well as in the second lactation imported cows had better yield than home cows. However, the difference in Swedish cows favour decreased after FCM calculation and was $184 \mathrm{~kg}$ in the first and $750 \mathrm{~kg}$ in the second lactation. The difference between milk yields was smaller for home cows. The milk yield advantage of home cattle in second lactation was $1253 \mathrm{~kg}$ while for imported cows $1991 \mathrm{~kg}$. The difference between fat and protein yield in $1^{\text {st }}$ and $2^{\text {nd }}$ lactation was as follows: imported cows $-63 \mathrm{~kg}$ of fat and $66 \mathrm{~kg}$ of protein, home cows $-45 \mathrm{~kg}$ and $39 \mathrm{~kg}$, respectively. Significant statistical differences were observed for $\mathrm{kg}$ of milk, for $\mathrm{kg}$ of protein, for FCM $(\mathrm{P}<0.01)$ and for $\mathrm{kg}$ of fat $(\mathrm{P}<0.05)$ in $2^{\text {nd }}$ lactation. Table I also showed that estimation coefficients for relationships between $1^{\text {st }}$ and $2^{\text {nd }}$ lactation was 1.33 for Sweden (group I) cows and 1.22 for home (group II) cows. This founds for home cows are similar with than that published CHLÁDEK and KUČERA (2002 a) for Holstein cows (1.175) or CHLÁDEK and KUČERA (2002 b) for Czech Pied cows (1.171). In opposite founds for Sweden cows are rather high.

CZERNIAWSKA-PIĄTKOWSKA (2004) found out, that mother cows from Sweden exceed their daughters imported to Poland in yield of milk (of about $2415 \mathrm{~kg})$, fat $(86 \mathrm{~kg})$ and protein $(87 \mathrm{~kg})$. KUCZAJ and BLICHARSKI (2001) reported that cows imported from Holland to Poland exceed their mothers in yield of milk (505 kg), fat $(26.4 \mathrm{~kg})$ and protein $(8.7 \mathrm{~kg})$. In the $1^{\text {st }}$ lactation they gained $7795 \mathrm{~kg}$ of milk, $342 \mathrm{~kg}$ of fat and $260 \mathrm{~kg}$ of protein. However PILARCZYK et al. (2004) stated that Dutch mother cows exceeded their daughters imported to Poland in yield of milk by $1986 \mathrm{~kg}$, fat $88.5 \mathrm{~kg}$, and protein $65.2 \mathrm{~kg}$. Those differences were statistically confirmed $(\mathrm{P}<0,01)$. Cowsdaughters in first lactation gained $5463 \mathrm{~kg}$ of milk, $237 \mathrm{~kg}$ of fat, and $193 \mathrm{~kg}$ of protein.

SABLIK et al. (2001) revealed that cows imported from France showed in following four lactations higher milk, fat, and protein yield comparing to home cows. In the study of GNYP et al. (2001) home cows and cows imported from Holland, comparing to cows imported from Germany and France, gained higher yield of milk and its components in $1^{\text {st }}$ and $2^{\text {nd }}$ lactation. The growth of milk yield in $2^{\text {nd }}$ lactation comparing 
to the $1^{\text {st }}$ one in home cows and these imported from Holland increased from 20 to $21 \%$. In the research of KUCZAJ (2002) cows imported from Holland, which were kept in the same conditions as Polish age mates black and red-white, gained in $1^{\text {st }}$ lactation less milk $(8214 \mathrm{~kg})$, but fat yield was higher $(424 \mathrm{~kg})$ and a little bit higher protein yield $(271 \mathrm{~kg})$.

I: Milk, fat and protein yield in first and second 305 days lactation in cows from Sweden (Group I) and home cows (Group II)

\begin{tabular}{|c|c|c|c|c|c|c|c|c|c|}
\hline \multirow{2}{*}{ Group } & \multirow{2}{*}{ Statistics } & \multicolumn{4}{|c|}{$1^{\text {st }}$ Lactation - Yield $(\mathrm{kg})$} & \multicolumn{4}{c|}{$2^{\text {nd }}$ Lactation - Yield (kg) } \\
\cline { 2 - 11 } & & Milk & Fat & Protein & FCM & Milk & Fat & Protein & FCM \\
\hline \multirow{3}{*}{ I } & $\overline{\mathrm{x}}$ & 5926 & 238 & 186 & 5941 & $7917 \mathrm{~A}$ & $301 \mathrm{a}$ & $252 \mathrm{~A}$ & $7683 \mathrm{~A}$ \\
\cline { 2 - 11 } & $\mathrm{s}_{\mathrm{x}}$ & 1008.22 & 40.20 & 31.56 & 982.95 & 1731.01 & 69.81 & 52.77 & 1701.44 \\
\cline { 2 - 11 } & $\mathrm{V} \%$ & 17.01 & 16.89 & 16.90 & 16.54 & 21.86 & 23.18 & 20.91 & 22.14 \\
\hline \multirow{3}{*}{$\mathrm{II}$} & $\overline{\mathrm{x}}$ & 5658 & 232 & 183 & 5757 & $6911 \mathrm{~A}$ & $277 \mathrm{a}$ & $222 \mathrm{~A}$ & $6933 \mathrm{~A}$ \\
\cline { 2 - 11 } & $\mathrm{s}_{\mathrm{x}}$ & 1244.63 & 50.97 & 36.66 & 1216.85 & 1508.23 & 58.87 & 44.63 & 1425.93 \\
\cline { 2 - 10 } & $\mathrm{V} \%$ & 22.00 & 21.88 & 19.95 & 21.13 & 21.82 & 21.18 & 20.03 & 20.57 \\
\hline
\end{tabular}

A... upper case letters within columns denote differences significant at $\mathrm{P} \leq 0.01$

a... lower case letters within columns denote differences significant at $\mathrm{P} \leq 0.05$

Table II presents the percentage of fat content in $1^{\text {st }}$ and $2^{\text {nd }}$ lactation (duration 305 days) and relations between milk components. The average percentage of fat $(4.17 \%)$ and protein $(3.26 \%)$ content in $1^{\text {st }}$ and the $2^{\text {nd }}$ lactation (3.99\% and $3.21 \%$, respectively) was higher for home cows comparing to imported cows. Significant differences were proved $(\mathrm{P}<0.01)$ excluding protein content in $2^{\text {nd }}$ lactation. In $2^{\text {nd }}$ lactation cows from Sweden obtained better protein to fat proportion (SBT) in milk by 0.04 and differences between the percentage of fat and protein content (RTB) in milk by $0.18 \%$. Those differences were proved statistically $(\mathrm{P}<0.01)$.

According to CZERNIAWSKA-PIĄTKOWSKA (2004) percentage of protein content in milk from cows kept in Sweden was higher (of $0.1 \%$ ) than in milk from their daughters imported to Poland. They also had lower RTB (of $0.28 \%$ ). Inversely, the percentage of fat content in milk, and STB was better (by 0.18 and $0.07 \%$, respectively) for daughters.
Observations of mother cows in Holland made by KUCZAJ and BLICHARSKI (2001) led to conclusion that cows had higher protein content in milk $(0.11 \%)$, better STB $(0.03)$ and RTB $(0.17 \%)$.

In KUCZAJ's (2004) study Dutch heifer cows, comparing to black-white and red-white Polish cows, gained higher percentage of fat content in milk $(5.18 \%)$ by $1.1 \%$ and $1.68 \%$ and just a bit higher protein content $(3.32 \%)$, by $0.07 \%$ and $0.05 \%$ in 305 days lactation. GNYP et al. (2001) stated that cows from France, comparing to animals from Holland, Germany and Poland, had significantly the lowest percentage of fat content in milk in $1^{\text {st }}(3.64 \%)$ but also in $2^{\text {nd }}(3.61 \%)$ lactation. However, German cows obtained higher content of this components in milk (4.16 and 4.34\%). Statistical differences concerning the percentage of fat content in milk in $1^{\text {st }}$ and $2^{\text {nd }}$ lactation between home animals and cattle imported from Holland were not significant. The authors noted significant differences $(\mathrm{P}<0.01)$ in $2^{\text {nd }}$ lactation, comparing home cows

II: Percentage of fat and proteins in first and second 305 days lactation and relations between those components in milk

\begin{tabular}{|c|c|c|c|c|c|c|c|c|c|}
\hline \multirow[t]{2}{*}{ Group } & \multirow[t]{2}{*}{ Statistics } & \multicolumn{2}{|c|}{$\begin{array}{l}1^{\text {st }} \text { Lactation } \\
- \text { Content } \%\end{array}$} & \multirow[t]{2}{*}{ SBT } & \multirow[t]{2}{*}{ RTB(\%) } & \multicolumn{2}{|c|}{$\begin{array}{l}2^{\text {nd }} \text { Lactation } \\
- \text { Content } \%\end{array}$} & \multirow[t]{2}{*}{ SBT } & \multirow[t]{2}{*}{$\operatorname{RTB}(\%)$} \\
\hline & & Fat & Protein & & & Fat & Protein & & \\
\hline \multirow{3}{*}{ I } & $\overline{\mathrm{x}}$ & $4.03 \mathrm{~A}$ & $3.15 \mathrm{~A}$ & 0.79 & 0.87 & $3.81 \mathrm{~A}$ & 3.20 & $0.85 \mathrm{~A}$ & $0.61 \mathrm{~A}$ \\
\hline & $s_{x}$ & 0.28 & 0,15 & 0.05 & 0.25 & 0.36 & 0.17 & 0.08 & 0.33 \\
\hline & $\mathrm{V} \%$ & 6.92 & 4.75 & 6.63 & 28.68 & 9.41 & 5.24 & 8.93 & 53.26 \\
\hline \multirow{3}{*}{ II } & $\overline{\mathrm{x}}$ & $4.17 \mathrm{~A}$ & $3.26 \mathrm{~A}$ & 0.79 & 0.90 & $3.99 \mathrm{~A}$ & 3.21 & $0.81 \mathrm{~A}$ & $0.79 \mathrm{~A}$ \\
\hline & $\mathrm{s}_{\mathrm{x}}$ & 0.40 & 0.21 & 0.05 & 0.29 & 0.41 & 0.20 & 0.08 & 0.38 \\
\hline & $\mathrm{V} \%$ & 9.59 & 6.45 & 6.86 & 32.33 & 10.27 & 6.27 & 10.13 & 48.39 \\
\hline
\end{tabular}

A... upper case letters within columns denote differences significant at $\mathrm{P} \leq 0.01$ 
with cows imported from Germany. Home and Dutch cows had higher proteins content in milk $\left(1^{\text {st }}\right.$ lactation $3.22 \%$ and $2^{\text {nd }} 3.31 \%$, and 3.26 and $3.35 \%$, respectively) than German and French cows. The differences were statistically significant $(\mathrm{P}<0.01)$.

Table III contains an average age of first calving of Swedish (916 days) and home cows (928 days). Statistically important differences were not stated. KAMIENIECKI et al. (2000) announce that the first calving should take place at age 2.5 years (910 days). Cows imported from Sweden and home cows differed slightly from this standard.

III: Average age at first calving of cows from Sweden (Group I) and home cows (Group II)

\begin{tabular}{|c|c|c|}
\hline Statistics & Group I & Group II \\
\hline$\overline{\mathrm{x}}$ & $\begin{array}{c}916 \text { days } \\
31 \text { months }\end{array}$ & $\begin{array}{c}928 \text { days } \\
31 \text { months }\end{array}$ \\
\hline $\mathrm{s}_{\mathrm{x}}$ & 113.59 & 128.43 \\
\hline $\mathrm{V} \%$ & 12.40 & 13.83 \\
\hline
\end{tabular}

WROŃSKI et al. (2001) stated that HolsteinFriesian heifers imported from Holland calved on the $815^{\text {th }}$ day of life, and home cows were 74 days older at first calving. WIELGOSZ-GROTH and GROTH (2002) published, that cows from Holland calved at age 811 days for the first time, and home cows at the age of 786 days. PIECH and TARKOWSKI (2003) stated that yield and length of performance is correlated with the age of first calving. The longest performance had cows with first calving taking place till $25^{\text {th }}$ month of life, the shortest- cows which calved after $30^{\text {th }}$ month of life.

Table IV shows the mean values of some fertility parameters of cows from Sweden and home cows. The gestation interval lasts 127 days for imported cows and 7 days longer for home cows. According to KAMIENIECKI et al.(2002) the optimum period is between 70 and 100 days. WROŃSKI et al. (2001) obtained similar results (at cows imported from Holland 128 days, at home cows 90 days).

IV: Mean values of some fertility parameters of cows from Sweden (Group I) and home cows (Group II)

\begin{tabular}{|c|c|c|c|c|}
\hline Group & Statistics & $\begin{array}{c}\text { GI } \\
\text { (days) }\end{array}$ & $\begin{array}{c}\text { CI } \\
\text { (days) }\end{array}$ & AII \\
\hline \multirow{3}{*}{ I } & $\overline{\mathrm{x}}$ & 127 & 409 & $1.15 \mathrm{~A}$ \\
\cline { 2 - 5 } & $\mathrm{s}_{\mathrm{x}}$ & 63.03 & 61.51 & 0.39 \\
\cline { 2 - 5 } & $\mathrm{V} \%$ & 49.60 & 15.04 & 33.9 \\
\hline \multirow{3}{*}{ II } & $\overline{\mathrm{x}}$ & 134 & 416 & $1.3 \mathrm{~A}$ \\
\cline { 2 - 5 } & $\mathrm{s}_{\mathrm{x}}$ & 70.43 & 72.47 & 0.61 \\
\cline { 2 - 5 } & $\mathrm{V} \%$ & 52.32 & 17.42 & 46.9 \\
\hline
\end{tabular}

A... upper case letters within columns denote differences significant at $\mathrm{P} \leq 0.01$

GI - gestation interval

$\mathrm{CI}$ - calving interval

AII - artificial insemination index

KRZYŻEWSKI et al. (2004) ended up with a conclusion, that in case of high milk yield (over $8000 \mathrm{~kg}$ in lactation) there is no possibility (without hormonal treatment) of 12-months gestation interval. This interval usually lasts 111 days in spite of proper feeding and good environment conditions.

According to KAMIENIECKI et al. (2002) the calving interval should last 365 days, but own researches did not prove this statement. MAŁECKI-TEPICHT et al. (2000) published that calving interval took 482 and 550 days (cows from France), 432 days (German cows) and 374 days (home cows).

DYMNICKI et al. (2003) noted that elongating calving interval, on every age stage, can lead to the increase of milk, fat and protein yield. Big differences were observed between heifers and older cows (lower level of parameters) starting from the second lactation. They found that the length of calving interval does not have an impact on the percentage of fat and protein content. And when this period lasts for 417 days (heifers) or 423 days (older cows) and milk production is closed to $7000 \mathrm{~kg}$ there can be some reproduction trouble.

According to KAMIENIECKI et al. (2002) the insemination index should be from 1.3 to 1.6 . In the research by KAMIENIECKI et al. (2000), the insemination index of cows imported from Germany was 2.2. SABLIK et al. (2001) reported that this index in fourth lactation reached values from 3.59 to 3.99 (cows imported from France) and from 1.95 to 2.44 (home cows). MALECKI-TEPICHT et al. (2000) ascertained that insemination index was unprofitable and was 3.02-3.26 (cows imported from France), 2.58 (cows imported from Germany) and 1.79 (home cows). WIELGOSZ-GROTH and GROTH (2002) reported values of 2.1 (home cows) and 2.21 (Dutch cows).

According to SABLIK et al. (2001) environmental factors (stress, improper nourishment, wrong heat detection, etc.) caused low reproduction performance. They also allude about so called physiological infertility which can be observed in high yielding cows. PILARCZYK et al. (2004) stated that introducing of cows with potentially high production possibilities into unfavorable environment can lead to the small, with the reference to carried efforts, yield increase or even to its decrease.

Import of animals with high breeding value requires providing of suitable conditions of welfare and nourishment, otherwise obtained production results might be lowered. 


\section{SOUHRN}

Porovnání mléčné užitkovosti a některých reprodukčních parametrů holštýnských krav importovaných ze Švédska s jejich vrstevnicemi v Polsku

V druhé polovině 80 . let byla v Polsku velkoplošně prováděna umělá inseminace krav a jalovic semenem Holštýnsko-frízských (HF) býků, což mělo za následek významné změny v černostrakaté populaci. V současné době je téměř 90 \% testovaných černostrakatých jalovic v Polsku kř́ženkami a polovina z nich má více než 50 \% HF genů. Zušlecht'ování domácího skotu mělo vliv na utváření těla a na mléčnou užitkovost, což v konečném důsledku vedlo k převedení populace na jednostraně mléčný typ skotu.

Cílem této práce bylo porovnání mléčné užitkovosti a některých reprodukčních parametrů holštýnských krav importovaných ze Švédska s jejich vrstevnicemi v Polsku. Porovnání bylo provedeno na dvou skupinách prvotelek. První skupina (Group I) zahrnovala 100 prvotelek importovaných ze Švédska v období dubna až května roku 2002 a druhá skupina (Group II) rovněž 100 čistokrevných (H100) prvotelek původem z Polska. Dojnice byly celoročně krmeny směsnou krmnou dávkou (TMR) založené na bázi objemných krmiv (kukuřičná siláž, travní senáž), koncentrátů (kukuřičné zrno) a různých doplňků (pivovarské mláto, cukrovarské řízky). Dojení probíhalo třikrát denně. Analýza byla prováděna na základě kontroly užitkovosti krav metodou $\mathrm{A}_{4}$. Mezi skupinami byly zjišt’ovány rozdíly v produkci mléka, produkci tuku a bílkovin a obsahu tuku a bílkovin. Byly analyzovány i rozdíly mezi složkami mléka pomocí poměru tuku a bílkovin (SBT) a rozdílu v koncentraci tuku a bílkovin (RBT) na 1. i 2. laktaci. Dojnice importované ze Švédska dosáhly při porovnání s domácími vyšších hodnot v produkci mléka i produkci mléčných složek na obou laktacích. Statisticky průkazné rozdíly však byly prokázány pouze na druhé laktaci v produkci mléka, bílkovin a FCM $(\mathrm{P}<0,01)$ a v produkci tuku $(\mathrm{P}<0,05)$. Obsah tuku a bílkovin v mléce domácích krav (Group II) byl vysoce statisticky průkázně $(\mathrm{P}<0,01)$ vyšší. Vysoce průkazný rozdíl $(\mathrm{P}<0,01)$ byl zjištěn i u poměru tuku a bílkovin (SBT) a rozdílu v obsahu tuku a bílkovin (RBT) u krav na 2. laktaci ve prospěch importovaných krav (Group I). Pokud jde o některé reprodukční ukazatele (mezidobí, servis perioda, inseminační index), vykázaly krávy importované ze Švédska lepší hodnoty a otelily se dř́ve.

import, dojnice, holštýn, mléčná užitkovost

\section{REFERENCES}

CHLÁDEK, G., KUČERA, J.: The relationship between milk production in the first three lactations of Holstein cows. Acta univ. agric. et silvic. Mendel. Brun., 2002 (a), L, No, pp. 13-18

CHLÁDEK, G., KUČERA, J.: Relationships between milk yields in the first three lactations of Czech Pied cows. Czech J. Anim. Sci., 47, 2002 (b), 11: 445450

CZERNIAWSKA-PIAॄTKOWSKA, E.: Wydajność i skład mleka utrzymywanych w Polsce pierwiastek w porównaniu z ich matkami w Szwecji. Med. Wet., 2004, 12: 1320-1322

DYMNICKI, E., KRZYŻEWSKI, J., OPRZAૃDEK, J., REKLEWSKI, Z., OPRZĄDEK, A.: Zależność między długością międzyocieleniowego a cechami użytkowości mlecznej krów rasy czarno-białej. Med. Wet., 2003, 9: 792-796

GNYP, J., KAMIENIECKI, K., KOWALSKI, P., MATYSKA, T.: Wydajność i skład mleka krów holsztyńsko-fryzyjskich krajowych i importowanych, utrzymywanych w gospodarstwach indywidu- alnych województwa lubelskiego. Zesz. Nauk. Prz. Hod, 2001, 59: 129-137

KAMIENIECKI, H., CZERNIAWSKA-PIĄTKOWSKA, E., DURNAŚ, B.: Wartość produkcyjna i reprodukcyjna stada krów rasy HF importowanych jako jałowice cielne z Niemiec. Mat. Konf. Naukow. nt. ,Zastosowanie biotechnologii w chowie i hodowli zwierząt oraz produkcji pasz i żywności” Szczecin-Międzyzdroje, 2000, 82-87

KAMIENIECKI, H., WÓJCIK, J., CZERNIAWSKAPIĄTKOWSKA, E., SABLIK, P., SZARKOWSKI, K.: Hodowla bydła skrypt do wykładów i ćwiczeń. AR Szczecin, 2002, 38-40

KRZYŻEWSKI, J., STRZAŁKOWSKA, N., REKLEWSKI, Z., DYMNICKI, E., RYNIEWICZ, Z.: Wpływ długości okresów międzyciążowych u kró rasy hf na wydajność, skład chemiczny mleka oraz wybrane wskaźniki reprodukcji. Med. Wet., 2004, 1: 76-79

KUCZAJ, M.: Dynamika zmian wydajności i składu chemicznego mleka krów pierwiastek czarnoi czerwono-białych w Polsce. Med. Wet, 2002, 4: 295-297

KUCZAJ, M.: Analiza wartości użytkowej krów 
rasy czarno-białej importowanych z Holandii i ich rówieśnic ras czarno- i czerwono-białej odchowanych w kraju. Med. Wet., 2004, 12: 1317-1319

KUCZAJ, M., BLICHARSKI, P.: Zawartość białka i tłuszczu w mleku krów rasy czarno-białej importowanych do Polski oraz ich matek utrzymywanych w Holandii. Med. Wet., 2001, 7: 518-521

KUČERA, J., CHLÁDEK, G., ŽIŽLAVSKÝ, J.: Analysis of the relationships between linear type traits and breeding values of milk production parameters in holstein dairy cows. Acta univ. Agric. Et silvic. Mendel. Brun., L, 2002, (1), pp. 139-144

LITWIŃCZUK, Z., GULIŃSKI, P.: Bydło holsztyńsko-fryzyjskie i jego wykorzystanie w doskonaleniu czarno-białego bydła mlecznego w Polsce i na świecie. Post. Nauk. Roln., 2000, 2: 71-87

MAŁECKI-TEPICHT, J., BARAŃSKI, W., JANOWSKI, T., CZAPLICKA, M.: Procesy rozrodu oraz płodność importowanych krów rasy holsztyńskofryzyjskiej. Prz. Hod., 2000, 2: 1-3.

PIECH, M., TARKOWSKI, J.: Wpływ wieku pierwszego ocielenia na produkcyjność krów czarno- białych z różnym udziałem genów rasy holsztyńsko-fryzyjskiej. Zesz. Nauk. Prz. Hod., 2003, 68: 153-159

PILARCZYK, R., KAMIENIECKI, H., WÓJCIK, J., CZERNIAWSKA-PIĄTKOWSKA, E.: Porównanie wydajności oraz składu mleka krów pierwiastek importowanych do Polski i ich matek w Holandii. Med. Wet., 2004, 8: 832-835

SABLIK, P., KAMIENIECKI, H., GRZESIAK, W.: Porównanie poziomu cech produkcyjnych i niektórych wskaźników rozrodczych krów holsztyńskofryzyjskich importowanych jako jałowice cielne z Francji z wynikami uzyskanymi od krów miejscowych. Zesz. Nauk. Prz. Hod., 2001, 59: 239-245

WIELGOSZ-GROTH, Z., GROTH, J.: Porównanie mleczności krów rasy HF wyhodowanej w Polsce i Holandii. Zesz. Nauk. Prz. Hod., 2002, 62: 55-61 WROŃSKI, M., CICHOCKI, M., KOSAKOWSKA, J.: Efektywność użytkowania importowanych z Holandii pierwiastek holsztyńsko-fryzyjskich w porównaniu z pierwiastkami uzyskanymi z własnego odchowu. Zesz. Nauk. Prz. Hod., 2001, 59: 289-299

Address

Dr. Ing. Ewa Czerniawska-Piątkowska, Oddělení výzkumu přežvýkavců, Zemědělská univerzita ve Štětíně, Doktora Judyma 10, Štětín, Polsko, Dr. Ing. Maciej Adamski, Oddělení chovu skotu a produkce mléka, Zemědělská univerzita ve Wroclavi, Chełmońskiego 38d, Wroclaw, Polsko, Ing. Daniel Falta, Ústav chovu a šlechtění zvířat, Mendelova zemědělská a lesnická univerzita v Brně, Zemědělská 1, 61300 Brno, Česká republika 